\title{
A note on the effect of rape seed oil supplementation on microbial protein synthesis in sheep
}

\author{
Malgorzata Szumacher-Strabel, A. Potkański and A. Cieślak
}

\author{
Department of Animal Nutrition and Feed Management, \\ Poznan Agriculture University \\ Wotyńska 33, 60-637 Poznań, Poland
}

(Received 10 March 1998: accepted 24 June 1998)

\begin{abstract}
The effect of rape seed oil on net microbial protein synthesis and other metabolic parameters was estimated on four rams fitted with rumen cannulas in a 4 x 4 Latin square design consisting of four diets differing in the percentage of rape seed oil supplement. The basal diet was composed of $50 \%$ concentrate and $50 \%$ meadow hay and was supplemented with 4,8 or $10 \%$ of rape seed oil. Supplementation of the diet with 4 and $8 \%$ of rape seed oil causcd a drop in net microbial protein production, determined by allantoin excretion in urine, but the differences were not significant. The highest dose of rape seed oil had no effect on the intestinal flow of microbial protein. Fat supplement had no influence on $\mathrm{pH}$ and ammonia- $\mathrm{N}$ or on total VFA, acetate and propionate concentrations. The butyrate concentration was, however, lower $(\mathrm{P}<0.05)$ when rape seed oil was added to the basal diet.
\end{abstract}

KEY WORDS: rumen, fat, microbial protein, allantoin, sheep

\section{INTRODUCTION}

It is difficult to meet energy requirements with forages or grain in animals already receiving maximum dry matter intake, hence the numerous attempts to increase the energy content of feeds for ruminants by increasing fat concentrations in diets (Sutton et al., 1983; Murphy et al., 1987). The main problem with a high level of fat is its effect on rumen microflora, which results in decreased cellulose digestion and reduced acetate/propionate ratio (Garnsworthy, 1997). On the other 
hand, diets supplemented with fat improve the efficiency of microbial protcin synthesis (Tesfa, 1993). The effect of fat added to ruminant rations has been the subject of considerable research, but there are many contradictory results. Furthermore, there is also a close relationship between microbial protein production measured by urinary allantoin excretion and diet composition (Puchala and Kulasek, 1992). Ben Salem et al. (1993) suggested that the negative effects of lipids on rumen digestion was less important when fibre intake was high.

The objective of this study was to evaluate the effect of added fat and concentrate/hay diet on basic ruminal parameters in sheep, mainly on net microbial protein synthesis.

\section{MATERIAL AND METHODS}

Animals, feeds and feeding

Four rumen cannulated rams of mean body weight of $50 \pm 3 \mathrm{~kg}$ were fed four diets in a Latin square design. The diets were formulated on the basis of rape seed oil (RSO) content (Table 1). The basal diet was $1.2 \mathrm{~kg} / \mathrm{d}$ of concentrate and hay $(50: 50 \% \mathrm{w} / \mathrm{w})$. RSO was mixed with concentrate while hay was chaffed into particles of $2-5 \mathrm{~cm}$ length. The encrgy value of the ration was $5.75 \mathrm{MJ} \mathrm{NE}$, and the crude protein content was $144 \mathrm{~g}$ per $\mathrm{kg}$. The animals were kept in individual pens and fed two equal portions of feed at 08.00 and 16.00 . They had free access to fresh water.

TABLE 1

Dicts composition, $\%$ of DM

\begin{tabular}{lrrrr}
\hline & \multicolumn{5}{c}{ Group } \\
\cline { 2 - 5 } & \multicolumn{1}{c}{ I } & II & III & IV \\
\hline Rapesced oilmeal & 3.0 & 3.0 & 3.0 & 3.0 \\
Wheat, ground & 12.0 & 11.0 & 11.0 & 11.0 \\
Rye, ground & 10.0 & 10.0 & 9.0 & 9.0 \\
Triticale, ground & 20.0 & 19.0 & 18.5 & 18.0 \\
Meadow hay & 53.0 & 51 & 48.5 & 47.0 \\
Rapc sced oil & 0.0 & 4.0 & 8.0 & 10.0 \\
Mineral-vitamin mixture & 1.5 & 1.5 & 1.5 & 1.5 \\
Trace mineral salt* & 0.5 & 0.5 & 0.5 & 0.5 \\
\hline
\end{tabular}

* contains $\mathrm{NaCl}-95.8 \%$

\section{Sampling}

Rumen fluid. Samples from ventral sac of rumen fluid were taken at 0 (prcfeeding), 3 and 6 h post-feeding during 2 consecutive days after an adaptation 


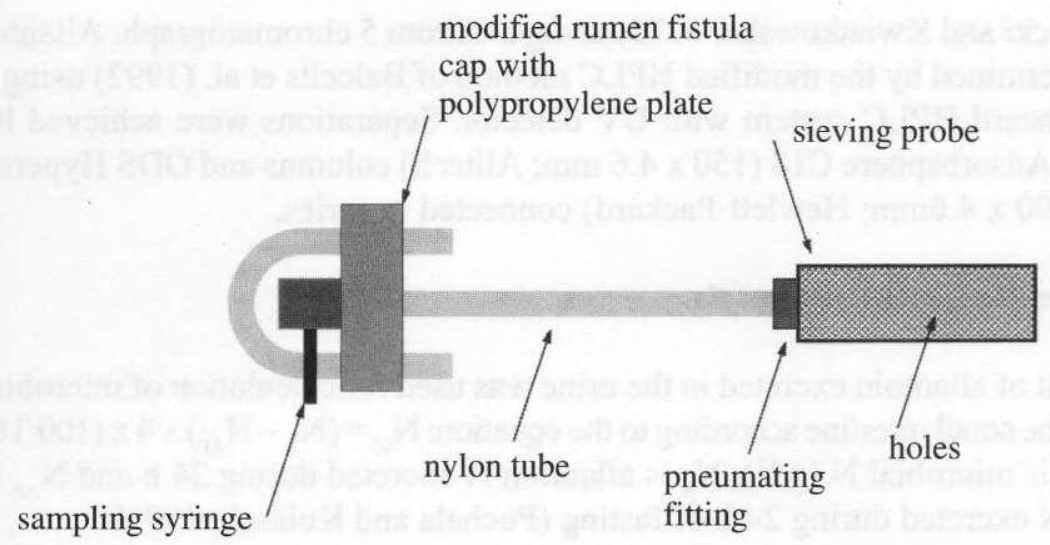

Figure 1. Sampling device

period to the diet (12 days). A sampling device which fits into a cannula cap (Figure 1) was used to collect the rumen fluid without access to oxygen. The sieving probe of the device is prepared from a solid block of polypropylene, $55 \mathrm{~mm}$ long with a diameter of $18 \mathrm{~mm}$. The block was hollowed out from the top to give a cylinder with about $2 \mathrm{~mm}$ walls (the base remains solid). Small holes are drilled into the walls of the cylinder. A pneumatic fitting joins the probe with the tubing (nylon tubing $6 \mathrm{~mm}$ diameter). The tubing is approximately $140 \mathrm{~mm}$ long. The second pneumatic fitting connects the tube to the sampling syringe. To take samples the blanking plug is removed from the tube and the end of a syringe is pushed into the push-in fitting giving a good connection. The modified rumen fistula cap is pushed over the polypropylene plate of the sampling device which then forms a secure closure. The polypropylene plate has the same diameter as the inside of the rumen fistula cap. It has three holes in it. The middle one is the same diameter as the tubing. The other two can be used for infusion if the dual marker system is being used, or can be blanked off by inserting a short piece of tubing in "U" shape through the two holes. The sampled rumen fluid was subsampled for ammonia-N $(20 \mathrm{ml})$ and VFAs $(20 \mathrm{ml})$ determination.

Urine. Urine was collected for $48 \mathrm{~h}$ according to Gonda and Lindberg (1997), and the collection was performed using a urine collection device (Kowalczyk et al., 1996). The collected urine was weighed and sampled every $24 \mathrm{~h}$. The samples were stored at $-20^{\circ} \mathrm{C}$ until analysis.

\section{Analytical methods}

Rumen $\mathrm{pH}$ was measured immediately after collection using a Mera Tronic $\mathrm{N}$ 517 pH-Meter. Ammonia was measured by the Conway method (1962). Volatile fatty acids were determined qualitatively and quantitatively by gas chromatogra- 
phy (Ziołecki and Kwiatkowska, 1973) using a Chrom 5 chromatograph. Allantoin was determined by the modified HPLC method of Balcells et al. (1992) using a Hewlett-Pacard HPLC system with UV detector. Separations were achieved by using two Adsorbsphere C 18 (150 x $4.6 \mathrm{~mm}$; Alltech) columns and ODS Hypersil column $(200 \times 4.6 \mathrm{~mm}$; Hewlett-Packard) connected in series.

\section{Calculation of microbial protein flow}

Amount of allantoin excreted in the urine was used for calculation of microbial $\mathrm{N}$ flow to the small intestine according to the equation: $\mathrm{N}_{M}=\left(\mathrm{N}_{\mathrm{A}}-\mathrm{N}_{A F}\right) \times 4 \times(100 / 18)$ wherc $N_{M}$ is microbial $N\left(g^{d-1}\right), N_{A}$ is allantoin $N$ excreted during $24 \mathrm{~h}$ and $N_{A F}$ is allantoin $\mathrm{N}$ excreted during $24 \mathrm{~h}$ of fasting (Puchala and Kulasck, 1992).

\section{Statistical calculations}

The results were subjected to statistical analysis of variance using SAS software program (User's Guide, 1988).

\section{RESULTS AND DISCUSSION}

\section{Intestinal flow of microbial protein}

Studies on the urinary excretion of purine derivatives by ruminants have been stimulated by the possible use of their excretion as evidence of the rumen microbial protein supplied to the host animal. This is because nucleic acids flowing to the small intestines in ruminants are essentially of microbial origin. Absorbed purines are degraded to hypoxanthine, xanthine, uric acid and allantoin, which are excreted in urine, and should relate quantitatively to the amount of purines and, hence, microbial protein absorbed (Chen et al., 1992).

Dewhurst at al. (1988) assumed that allantoin- $\mathrm{N}$ represents $86 \%$ of purine $\mathrm{N}$, which is absorbed from the gut with $86 \%$ efficiency. Some authors report that allantoin accounts for $85-90 \%$ of the total excretion of purine derivatives (Verbič et al., 1990; Vagnoni and Broderick, 1997). In fact some other authors suggested that when all purine derivatives are taken into consideration, quantitative assessment of microbial protein reaching the small intestine can be more accurate than that using allantoin alone (Czauderna and Kowalczyk, 1995).

In our experiment, allantoin was used for calculation of net microbial protein synthesis. Urinary excretion of allantoin was not significantly affected by the experimental treatments. The amounts of microbial nitrogen $\left(N_{M}\right)$ calculated from urinary allantoin excretion were $12.57,10.21,10.53$ and $12.05 \mathrm{~g} \mathrm{~N}_{\mathrm{M}} / \mathrm{d}$, in groups I, 
II, III and IV, respectively (Tablc 2). According to Elliot et al. (1995) replacement of nonstructural carbohydrates such as starch, decreases the amount of energy that is available for microorganisms and may decrease microbial protein synthesis. We also observed some decrease in $\mathrm{N}_{M}$ when the diet was supplemented with 4 and $8 \%$ RSO (see Tables 1 and 2 ). The differences, however, were statistically insignificant $(P>0.05)$. On the other hand, Murphy et al. (1987) found a positive correlation between the amount of fat added and net microbial protein synthesis when milking cows were fed rape seeds. A similar relationship was observed by Sutton et al. (1983) in relation to sheep fed a ration with linseed oil. If fat in the diet is to be fed successfully, it is recommended that ruminants consume the proper amount of fibre. Fibre minimizes the potential for negative effects of fat on rumen microbes (Grant and Weidner, 1992). In our experiment, sheep were fed equal portions of concentrate and roughage containing structural carbohydrates so none of the basic constituents was neglected. Further experiments with various levels of fibre in diets seem to be necessary.

\section{Ruminal fermentation characteristics}

The effect of added fat on $\mathrm{pH}$ and ammonia- $\mathrm{N}$ content in rumen fluid are shown in Table 2. The values were similar in all groups and ranged from 6.4 to 6.5 for $\mathrm{pH}$ and 4.2 to $5.8 \mathrm{mmol} / 1$ for ammonia- $\mathrm{N}$, respectively. The level of ammonia-N was low, especially in the control group, and tended to increase as the amount of rape seed oil increased, but the differences were not statistically significant. In contrast with this, Tesfa (1993) reported a reduction in ammonia- $\mathrm{N}$ concentration when Fresian bulls were fed a basal diet supplemented with $0.5 \mathrm{~kg}$ RSO from $9.61 \mathrm{mmol}$ to $6.26 \mathrm{mmol}$ in the basal and RSO groups, respectively. Similarly, feeding supplementary fat has been observed by Hall ct al. (1990) to depress rumen ammonia concentration. Also, in our earlier experiment, the addition of 3 and $6 \%$ of RSO to the diet of sheep caused a significant depression in ammonia- $\mathrm{N}$ concentration from 14.8 (control group) to $11.0 \mathrm{mmol}$ and $8.5 \mathrm{mmol}$, respectively (Szumacher-Strabel and Potkański, 1997).

TABLE 2

Effect diets of on net microbial protein synthesis, rumen $\mathrm{pH}$ and the concentration of $\mathrm{NH}_{3}-\mathrm{N}$ in the rumen of sheep

\begin{tabular}{lrrrr}
\hline & \multicolumn{4}{c}{ Group } \\
\cline { 2 - 5 } & \multicolumn{1}{c}{ I } & \multicolumn{1}{c}{ II } & \multicolumn{1}{c}{ III } & \multicolumn{1}{c}{ IV } \\
\hline $\mathrm{N}_{\mathrm{M}}, \mathrm{g} / \mathrm{d}$ & $12.57 \pm 3.42$ & $10.21 \pm 2.54$ & $10.53 \pm 3.27$ & $12.05 \pm 4.03$ \\
$\mathrm{NH}_{3}-\mathrm{N}, \mathrm{mmol}$ & $4.29 \pm 2.43$ & $5.08 \pm 2.30$ & $5.80 \pm 3.83$ & $5.87 \pm 4.59$ \\
$\mathrm{pH}$ & $6.46 \pm 0.61$ & $6.42 \pm 0.63$ & $6.53 \pm 0.62$ & $6.46 \pm 0.68$ \\
\hline
\end{tabular}


TABLE 3

Concentration of total and individual VFA

\begin{tabular}{lrrrr}
\hline & \multicolumn{4}{c}{ Group } \\
\cline { 2 - 5 } & \multicolumn{1}{c}{ I } & \multicolumn{1}{c}{ II } & \multicolumn{1}{c}{ III } & \multicolumn{1}{c}{ IV } \\
\hline Total VFA & $74.82+16.99$ & $79.39 \pm 17.13$ & $78.36 \pm 16.25$ & $82.74 \pm 15.20$ \\
Acetonic & $44.71 \pm 7.17$ & $38.68 \pm 10.21$ & $44.09 \pm 7.07$ & $36.73 \pm 12.76$ \\
Propionic & $23.06 \pm 3.71$ & $20.28 \pm 4.03$ & $21.61=5.04$ & $22.99 \pm 7.16$ \\
Butyric & $11.94^{\mathrm{A}} \pm 2.83$ & $9.26^{\mathrm{B}} \pm 1.97$ & $9.84^{\wedge \mathrm{B}} \pm 3.80$ & $8.16^{\mathrm{B}} \pm 2.46$ \\
Isobutyric & $2.36 \pm 0.43$ & $2.17 \pm 0.64$ & $2.27 \pm 0.61$ & $2.50 \pm 0.92$ \\
Valeric & $2.00 \pm 0.76$ & $1.59 \pm 0.59$ & $2.07 \pm 0.92$ & $1.55 \pm 0.74$ \\
Isovaleric & $1.83 \pm 0.62$ & $1.72 \pm 0.37$ & $2.18 \pm 0.82$ & $1.66 \pm 2.46$ \\
\hline
\end{tabular}

$\mathrm{A}, \mathrm{B}-\mathrm{P}<0.01$

$\mathrm{pH}$ values were not significantly affected by treatment. These observations are consistent with those reported by Murphy et al. (1987) in lactating cows fed diets containing full-fat rape seeds. In an experiment by Kowalczyk et al. (1977) rumen $\mathrm{pH}$ tended to increase with as the amount of tallow in diets for sheep rose $(0,50$, $100,150 \mathrm{~g}$ of tallow $/ \mathrm{kg}$ grass) .

There were no significant effects of RSO on the VFA level. The butyric acid concentration, however, was significantly reduced $(\mathrm{P}<0.05)$ in animals fed dicts supplemented with RSO (Table 3). According to Tesfa (1993), who obtained similar results, the decrease in butyrate concentration was accompanied by a decrease in the number of ciliates. This suggests that RSO could influence the fermentation pattern in the rumen affecting the composition of the rumen microbial population.

According to Tackett et al. (1996) supplementation of unprotected fats generally has a negative influence on ruminal fermentation. In our study, there was no negative effect of rape seed oil in the range from 4 to $10 \%$ on rumen parameters. We observed a positive effect up to $8 \%$ and a small depression at $10 \%$.

In conclusion, the experiment supports the assumption that feeding RSO to ruminants does not necessarily depress net microbial protein synthesis, but this depends on the quantity of added fat.

\section{REFERENCES}

Balcells J., Guada J.A., Peiro J.M., 1992. Simultaneous determination of allantoin and oxypuirines in biological fluids by high-performance liquid chromatography. J. Chromatogr. 575, 153-157

Ben Salem H., Krzemiński R., Ferlay A., Doreau M., 1993. Effect of lipid supply on in vivo digestion in cows: comparison of hay and silage diets. Can. J. Anim. Sci. 73, 547-557 
Chen X.B., Grubic G., Ørskov E.R, Osuji P., 1992. Effect of feeding frequency on diurnal variation in plasma and urinary purine derivatives in steers. Anim. Prod. 55, 185-191

Conway E.J., 1962. Microdiffusion $\Lambda$ nalysis and Volumetric Error. Crosby Lockwood, London

Czauderna M., Kowalczyk J., 1995. Determination of allantoin in blood by high-performance liquid chromatography with pre-column derivatization. J. Anim. Feed Sci. 4, 351-358

Dcwhurst R.J., Waters C.J., Webster A.J.F., 1988. Assesment of the energetic efficiency of rumen microbial protein yield using allantoin excretion. Proceedings of International Symposium on Protein Metabolism and Nutrition. Rostock (Germany)

Elliot J.P., Drackley J.K., Fahey G.C.Jr, Shanks R.D., 1995. Utilization of supplemental fat by dairy cows fed diets varying in content of nonstractural carbohydrates. J. Dairy Sci. 78, 1512-1525

Garnworthy P.C., 1997. Fats in dairy cow diets. In: P.C. Garnsworthy, J.Wiseman (Editors). Recent advances in animal nutrition. Nottingham University Press, pp. 87-104

Gonda H. L., Lindberg J.F., 1997. Eflect of diet on milk allantoin and its ralationship with urinary allantoin in dairy cows. J. Dairy Sci, 80, 364-373

Grant R.J, Weidner S.J., 1992. Effect of fat from whole soybeans on performance of dairy cows fed rations differing in fiber level and particle size. J. Dairy Sci. 75, 2742-2751

Hall K.L., Goetsch A.L., Landis K.M., Forster Jr.L.A., Brake A.C., 1990. Effects of fat and ground maize supplement on feed intake and digestion by cattle consuming bermuda grass hay ( $C$ nnodon dactolon). Anim. Feed Sci. Technol. 30, 275-288

Kowalczyk J., Ørskov E.R., Robinson J.J., Stcwart C.S., 1977. Effect of fat supplementation on voluntary food intake and rumen metabolism in sheep. Brit J. Nutr. 37, 251- 257

Kowalczyk I., Skiba B., Buczkowski Z., Kowalik B., 1996. A device for quantitative urine collection from male sheep in balance trials. J. Anim.Feed Sci. 5, 297-301

Murphy M., Uden P., Palınquist D.L., Wiktorsson II., 1987. Rumen and total diet digestibility in lactating cows fed diets containing fullfat rapeseed. J.Dairy Sci 70, 15-

Puchala R., Kulasek G.W., 1992. Fstimation of microbial protein flow from the rumen of shecp using microbial nucleic acid and urinary excretion of purine derivatives. Can. J. Anim. Sci.72, $821-830$

SAS, 1990. SAS/STAT Uscrs Guide (Release 6.03). SAS Institute Inc., Cary, NC, USA

Sutton J.D., Knight R., McAllan A.B., Smith R.H., 1983. Digestion and synthesis in the rumen of sheep given diets supplemented with free and protected oils. Brit. J. Nutr. 49, 419-432

Szumacher-Strabel M., Potkański A., 1997. A note on the effect of rape seed oil in concentrate/hay ration on microbial protcin synthesis in sheep. J. Anim. Feed Sci. 6, 499-505

Tackett V.L., Bertrand J.A., Jenkins 'T.C., Pardue F.E., Grimes L.W., 1996. Interaction of dietary fat and acid detergent fiber diets of lactating dairy cows. J. Dairy Sci. 79, 279-275

Tesfa A.T.,1993. Effects of rape-seed oil supplementation on digestion, microbial amino acid composition in ruminants. Anim. Feed Sci. Technol. 41, 313-328

Vagaoni D.B., Broderick G.A., 1997. Effects of supplementation of energy or ruminally undegraded protein to lactating cows fed alfalfa hay or silage. J. Dairy Sci. 80, 1703-1712

Verbič J., Chen X.B., Macleod N.A., Ørskov E.R., 1990. Excretion of purine derivatives by ruminants. Effect of microbial nucleic acid infusion on purine derivative excretion by steers. J. Agric. Sci., Camb.114, 243-248

Ziolecki A., Kwiatkowska E., 1973. Gas chromatography of $\mathrm{C}_{1}$ to $\mathrm{C}_{5}$ fatty acids in rumen and fermentation media. J. Chromatogr. 80, 250-254 


\section{STRESZCZENIE}

\section{Wplyw dodatku oleju rzepakowego na syntezę bialka mikroorganizmów w żwaczu u owiec}

Na czterech owcach, z trwałymi przetokami żwacza, badano wpływ zróżnicowancgo dodatku oleju rzepakowego $(4,8$ i $10 \%)$ do diety, składającej się z. $50 \%$ paszy tré́ciwej i $50 \%$ siana, na produkcję białka drobnoustrojowego, stosując alantoinę wydalaną w moczu jako wskaźnik. Oznaczono $\mathrm{pH}$, N-amonowy i LKT w płynic żwaczowym.

Dodatek 4 i 8\% oleju spowodował obniżenie produkcji białka drobnoustrojowcgo, jednakże w stopniu statycznie nieistotnym. Dodatek thuszczu nie miał także wpływu na pH i poziom N-amonowego. Tłuszcz dodany do diety obnizył poziom kwasu masłowego $\left(\mathrm{P}^{\mathrm{P}}<0.05\right)$ we wszystkich grupach w porównaniu $z$ grupą kontrolną. 